\title{
Itaquaquecetuba Formation, São Paulo basin, Brazil: new angiosperm components of Paleogene Taphoflora
}

\author{
Formação Itaquaquecetuba, bacia de São Paulo, Brasil: novos \\ componentes angiospérmicos da Tafoflora Paleógena
}

\section{Carlos Humberto Biagolini ${ }^{1}$, Mary Elizabeth Cerruti Bernardes-de-Oliveira ${ }^{1,2 *}$, Alexandra Guedes Caramês ${ }^{1}$}

\begin{abstract}
Among the various geological formations found in the State of São Paulo, the Itaquaquecetuba Formation, located in the São Paulo sedimentary basin, is one of the richest in Cenozoic plant fossils, allowing a detailed study of the flora which existed in that region, from the Paleogene to the Early Neogene. The plants identified in this formation, in general, belong to the families Melastomataceae and Fabaceae of the angiosperms group. In this study, one foliar impression of Leandra (Melastomataceae), being this the first fossil record of the genus, and one of Baubinia (Fabaceae) were identified. These foliar fragments allowed us to observe in detail the leaf architecture and then to carry out the generic assignment. The form assigned to the genus Leandra resembles more the current species L. acutiflora and that assigned to the genus Baubinia suggests affinity with $B$. divaricata. However, the ancient registration and the lack of an accuracy of the diagnostic characteristics lead us to use Leandra sp. and Bauhinia aff. B. divaricata designations. Some aspects of the paleogeography of both genera are discussed.
\end{abstract}

KEYWORDS: Atlantic Forest; Leandra; Bauhinia; Paleogene flora; São Paulo Basin; Brazil.

\section{INTRODUCTION}

The Itaquaquecetuba Formation is a lithostratigraphic unit of the São Paulo sedimentary basin, which has a rich fossil plants record, whose taxonomic identification allows a better understanding of the type of flora that existed in the São Paulo region, about $30 \mathrm{Ma}$. The macrofossils documenting such vegetation were studied by Fittipaldi and Simóes (1989), Fittipaldi et al. (1989) and Fittipaldi (1990, 2002). On the other hand, their palynomorphs were studied by Santos (2005), Santos et al.
RESUMO: Dentre as diversas formaçôes geológicas encontradas no Estado, a Formação Itaquaquecetuba, localizada na bacia sedimentar de São Paulo, é uma das mais ricas em fitofósseis cenozoicos, permitindo, assim, o estudo da flora que existia na região da grande São Paulo, no intervalo de tempo Paleógeno a Eoneógeno. A maioria dos vegetais identificados nessa formação é de angiospermas pertencentes às famílias Melastomataceae e Fabaceae. No presente estudo, identificaram-se: um fitofóssil de Leandra (Melastomataceae), sendo este o primeiro registro fossilifero do gênero, e um fitofóssil de Bauhinia (Fabaceae). Esses fragmentos de impressóes foliares permitem observar a arquitetura foliar com certo detalhe e, assim, fazer a identificação genérica. A forma atribuida ao gênero Leandra assemelha-se mais à espécie atual L. acutiflora, e aquela atribuida ao gênero Baubinia sugere afinidade com B. divaricata. Entretanto, a antiguidade do registro e a falta de características diagnósticas mais apuradas levam à adoção das designaçōes Leandra sp. e Bauhinia aff. B. divaricata. Alguns aspectos sobre a paleogeografía de ambos os gêneros são discutidos.

PALAVRAS-CHAVE: Mata Atlântica; Leandra; Baubinia; flora Paleógena; Bacia de São Paulo; Brasil.

(2006a, 2006b) and Santos (2008). Currently, new angiosperm components are incorporated into a diversified list that comprises mosses, ferns, gymnosperms and angiosperms.

\section{REGIONAL GEOLOGY AND AREA}

The São Paulo Cenozoic sedimentary basin included on the Atlantic Plateau is located in the Southeastern Brazil Continental Rift (Riccomini et al. 2004). It lies on

${ }^{1}$ Mestrado em Análise Geoambiental, Centro de Pós-Graduação e Pesquisa, Universidade Guarulhos - UnG, Guarulhos (SP), Brasil. E-mails: carloshbiagolini@ig.com.br; alexandra_carames@yahoo.com.br

${ }^{2}$ Programa de Pós-Graduação em Geotectônica e Geoquímica, Instituto de Geociências, Universidade de São Paulo - USP, São Paulo (SP), Brasil. E-mail: maryeliz@usp.br *Autor Correspondente

Manuscrito ID 29933. Recebido em: 08/03/2013. Aprovado em: 22/11/2013 
the Precambrian crystalline basement (Melo et al. 1986), whose substrate presents local uplifts and reliefs, formed by the action of pre- and post-sedimentary faults (Riccomini et al. 2004). The system of faults called Taxaquara-Jaguari is highlighted by its rectilinear northern border, while its southern border presents itself marked by irregular contacts with the Precambrian basement (Takiya 1997, Riccomini et al. 2004) (Fig. 1).

The depositional environment of the basin happened under strong tectonic conditions characterized by a hemi-grabens
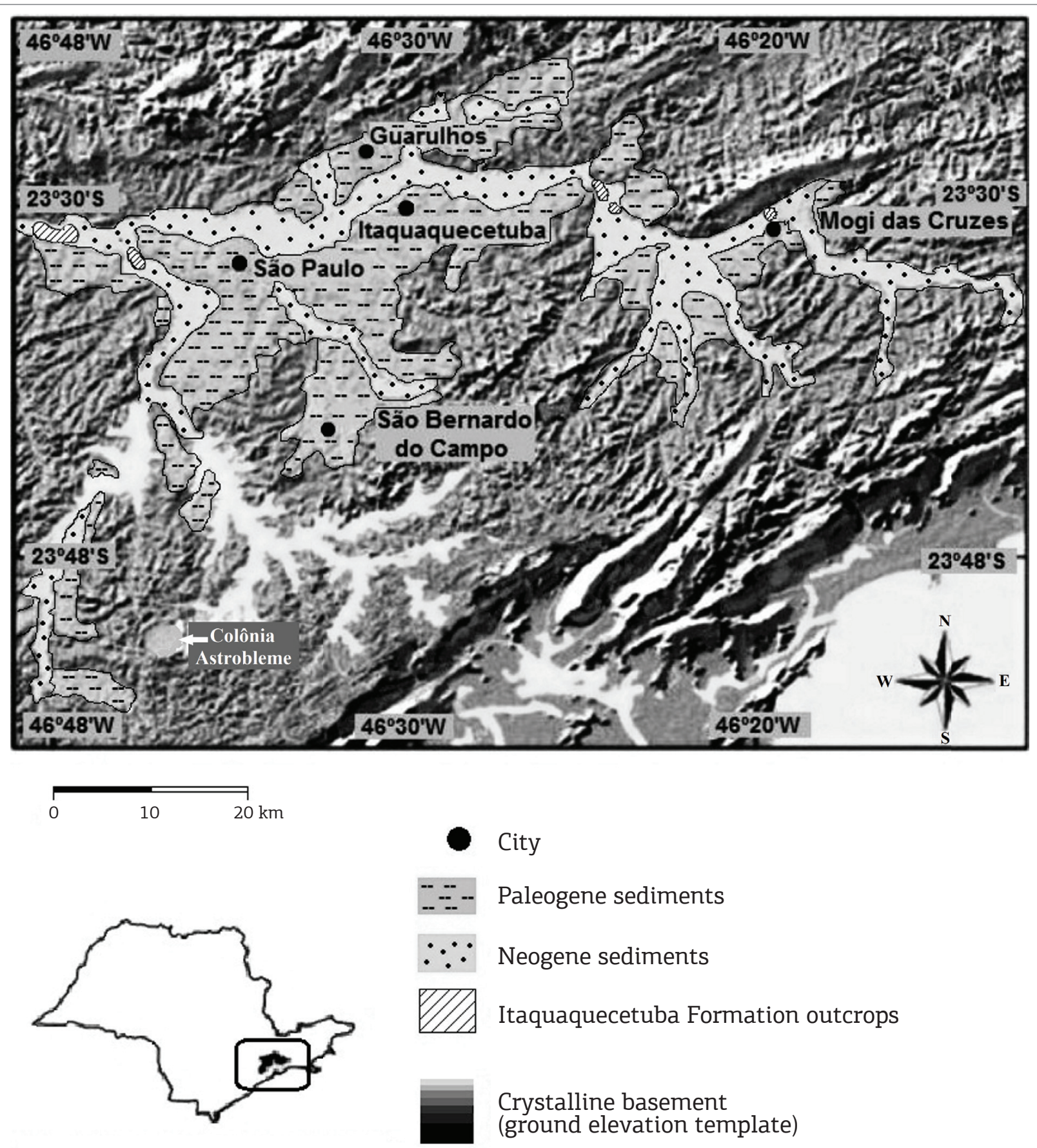

São Paulo basin location Eastern São Paulo State

Source: modified from Riccomini et al. (2004).

Figure 1. Map of the São Paulo sedimentary basin. 
system tilted toward NNW, being the Baquirivu-Guaçu Graben the most notable. The tectonic activities determined that the northern border of the basin, the proximal sedimentation area, was filled with predominance of coarse fanglomeratic deposits, grading, toward the south, to sandy mudstone sediments of distal environment (Campos et al. 2002).

The basin continental sediments are irregularly distributed, occupying an area of just over $1,000 \mathrm{~km}^{2}$. This area coincides roughly with the São Paulo municipality area, extending from the towns of Arujá toward Embu Guaçu up to $75 \mathrm{~km}$, and from Santana (district of São Paulo) to the city of Santo André, by $25 \mathrm{~km}$. There are also eastward branches, passing through the cities of Mogi das Cruzes, Biritiba Mirim and around Salesópolis and southward to Engenheiro Marsillac (district of São Paulo), these branches less significant in terms of area (Riccomini \& Coimbra 1992, Takiya 1997, Riccomini et al. 2004). The circular feature known as Colônia Astrobleme is an important area of the basin, isolated from the main sediment core and a result of a meteorite or comet impact. In its crater, a thickness of over 400 m of Late Cenozoic sediments was accumulated (Riccomini et al. 1992).

The lithostratigraphic units that constitute the São Paulo sedimentary basin correspond to the following formations: Resende, Tremembé, São Paulo and Itaquaquecetuba. This sequence is completed with quaternary alluvium and colluvium covers that occupy the plains of the major rivers in the Alto Tietê Hidrographic Basin.

The Itaquaquecetuba Formation has a classic sequence consisting of arkosean coarse sandstones with sub angular to angular grains, not well selected, indicative of a short transportation and/or proximity of the source area. As other units constituting the São Paulo basin, the Itaquaquecetuba Formation sediments had also the Precambrian crystalline basement rocks as source area. Zanão et al. (2006) also mentioned the presence of diamictites and mudstones/shales in the Itaquareia 1 Mine outcropping section.

The strata can contain silty clay levels, sometimes sandy, colored greenish gray (5/10Y, after Munsell Color System), and rich in organic matter. The sediments contain a high percentage of sand, varying in thickness from 20 to $130 \mathrm{~m}$, found in the alluvial deposits of the Tietê (near São Jorge Park) and Pinheiros rivers (Takiya 1997, Campos et al. 2002). Conglomeratic levels are abundant and composed primarily of quartz and quartzite pebbles. Cementation by marcasite is often noted, being indicative of a reducing environment (Coimbra et al. 1983).

The beds display trough and tabular cross-bedding stratifications, of a braided fluvial system, associated with alluvial fans. Palaeocurrent analysis on cross-bedding stratifications and on imbricate pebbles showed preferential dips to the NW and SW, thus indicating palaeocurrent coming from NE and SE (Coimbra et al. 1983).
The Itaquaquecetuba Formation is observed mainly in levels below $710 \mathrm{~m}$ under the alluvial sediments of the Tietê, Tamanduateí and Pinheiros rivers.

The depositional system of the Formation received a new interpretation after the studies made by Zanão et al. (2006), based on field survey stratigraphic sections in which they recognized nine distinct lithofacies in eight sedimentary cycles. The eight cycles showed fining-upward, with bases consisting of conglomeratic or coarse sandstones and their tops, by mudstones.

Zanão et al. (2006) proposed for the Formation in this area a system of alluvial fans deposition, with meandering fluvial facies associated to the ribbon-type channels, i.e. narrow and fixed channels with width/depth less than 15 times. These channels are usually associated with alluvial fans in places where there is an uplift of the source area.

Bedani and Saad (2009) proposed, based on Zanão et al. (2006) and Santos (2008) data, that the stratigraphic position of the Itaquaquecetuba Formation was equivalent to that of Resende Formation as in terms of depositional system as in age, suggesting a new lithostratigraphic scheme for the Paleogene of the São Paulo basin.

The Itaquaquecetuba Formation paleontological register was first reported by Tolentino (1965), who referred to the presence of a pyritized fossil coal in the São Paulo basin sediments, near the Campus of the University of São Paulo. They were carbonized stem fragments at the stage of xyloid lignite, spread in sand at $10 \mathrm{~m}$ depth.

The first paleontological studies were developed by Suguio and Takahashi (1970) and Suguio (1971), who analyzed fossil woods partially replaced by marcasite, from the Campus of the Universidade de Sáo Paulo, margin of Pinheiros River. The genera Myrocarpus, Centrolobium and Piptadenia (Fabaceae), Sloania (Elaeocarpaceae) and Myconia (Melastomataceae) were recognized and suggest a humid tropical climate. This formation was dated up to $40 \mathrm{kya}$ by $\mathrm{C}^{14}$, thus exceeding the accuracy of the method.

Suguio and Mussa (1978) studied silicified fossil woods, coming from Itaquareia 1 Mine, in the municipality of Itaquaquecetuba, identifying Astronioxylon mainieri (Anacardiaceae), Piptadenioxylon chimeloi (Fabaceae-Mimosoideae), Myrocarpoxylon sanpaulense (Fabaceae-Faboideae), Matayboxylon tietense (Sapindaceae), and Qualeoxylon itaquaquecetubense (Vochysiaceae). All living genera with botanical affinities to these forms are typical mainly of the Atlantic rainforest, semi-deciduous altitude latifoliated forest and Paraná basin.

Fittipaldi and Simóes $(1989,1990)$ and Fittipaldi (1990, 2002) studied macrofossils preserved as leaves and fruits, also coming from one area of the Itaquareia 1 Mine. These studies resulted in the assignment of the 
following taxa: Isotachis simonensi (Bryophyta), Lindsaea pradoi (Monilophyta), Echinodorus rossiae (Alismataceae), Aquifoliphyllum ilicioides (Aquifoliaceae), Monstera marginata (Araceae), Piptadenia tertiaria (FabaceaeMimosoideae), Cassia rosleri, Schizolobium inaequilaterum (Fabaceae-Caesalpinoideae), Machaerium piranii (Fabaceae-Faboideae), Casearia serrata (Flacourtiaceae), Ocotea pulchelliformis (Lauraceae), Byrsonima bullata (Malpighiaceae), Bertolonia coimbrae (Melastomataceae), Myrcia cf. $M$. rostrataformis and Psidium paulense (Myrtaceae), Rhamniphyllum caseariformis (Rhamnaceae), Tocoyena riccominii (Rubiaceae), Zanthoxylon glanduliferum (Rutaceae), Serjania lancifolia, S. itaquaquecetubensis (Sapindaceae), Luehea divaricatiformis (Malvaceae), and Sophora giuliettiae (Fabaceae-Faboideae).

The palynology of the type section base in Itaquareia 1 Mine was studied by Melo et al. (1985), who suggested the Late Eocene age while Lima et al. (1991), when analyzing samples from this section and others from the town of Barueri, attributed the Oligocene age to the studied sections, arguing that the presence of certain palynomorphs is due to reworking of older rock units.

Yamamoto (1995), studying samples of pollen grains of the Itaquaquecetuba Formation, from the same mining area, assigned the Oligocene-Miocene age to that lithostratigraphic unit.

Various samples collected at different levels of the Formation type section were palynologically analyzed by Santos (2005), suggesting the Late Eocene-Oligocene age for the base of the section and Early Miocene age for the medium to the top part of the section, with reworking of some Late Eocene-Oligocene palynomorphs.

However, Santos (2008), when making the pollen analysis of the stratigraphic sections surveyed by Zanáo et al. (2006), concluded that major part of the old section is Late Eocene in age while the upper third of the section is Early Oligocene.

After this author, the most important palynomorph forms as indicative of the Late Eocene intervals are: Echitriletes muelleri (Selaginellaceae), Cicatricosisporites dorogensis (Anemiaceae), Spinizonocolpites echinatus (Arecaceae), Ulmoideipites krempii (Ulmaceae), Margocolporites vanweijhei (Fabaceae-Caesalpinoideae), Polyadopollenites sp., Acaciapollenites sp. and Quadraplanus sp. (FabaceaeMimosoideae), Striatipollis catatumbus (Fabaceae), Perisyncolporites pokornii (Malpighiaceae), Echiperiporites akanthos (Malvaceae), Catinipollis geiseltalensis (Martiniaceae) and Perfotricolpites digitatus (Convolvulaceae).

For the Early Oligocene interval, there is a clear increase in the quantities of gymnosperms pollen grains as Podocarpidites sp. and Dacridiumites florinii (Podocarpaceae), besides the reduction in the quantity and diversity of angiosperms, especially Proteacidites dehanii (Proteaceae), Tricolpites reticulatus (Gunneraceae), Psilatricolpites operculatus (Euphorbiaceae) and Magnaperiporites spinosus (Malvaceae).

Based on the palynological content and on the stratigraphic relationships, the ages assigned to the Itaquaquecetuba Formation can be viewed in Fig. 2 .

\section{MATERIAL AND METHODS}

The material studied here was collected from an outcropping section of the Itaquaquecetuba Formation now completely destroyed by exploitation of sand in the area of the Itaquareia I Mine, in the municipality of Itaquaquecetuba, State of São Paulo. A facies profiles correlation section, surveyed at the samples recovering time, with modifications, is reproduced in the Fig. 3, indicating the provenance levels of the plant fossils samples and the studied palynomorphs.

As previously noted, the taphofloristic assembly is consisted of leaves in chaotic layout and sparse distribution, where many were reduced to fragments during transport to the site of deposition (biostratinomic implications), while others, by becoming extremely fragile on the weathered matrix, fragmented during collection or transport from the field to the laboratory and/or handling during the analysis. There are foliar specimens preserved as impression, compression or marcasitization that, despite the fragmentation, preserved the morphographic features as margins, base form and/or apex, and in some cases, allow observation of the secondary venation and even higher orders.

The specimens were examined under a C. Zeiss stereomicroscope (Stemi SV 6) in the Laboratory of Palynology and Paleobotany, Guarulhos University, and in the Laboratory of Paleobotany and Palynology of the Geosciences Institute, University of Sáo Paulo. To enhance the observation, drawings were made with camera lucida and on photos on a light table. The linear and angular morphographic features were measured using goniometer (Pilot's Shop) and digital caliper (Mitutoyo Digimatic Caliper) on fossils or on their scaled drawings.

The specimens presented here were deposited in the Guarulhos University Scientific Types Collection under the numbers UnG / 3T-153 and UnG / 3T-154.

Leaf specimens recovered as exsiccates from herbaria or in natura were clarified through chemical process, according Foster (1952) method, described by Dutra and Stranz (2002), to serve as a comparison in the taxonomic identification of the analyzed fossil remains. They were also deposited in the Guarulhos University Clarified Leaves Scientific Collection under the numbers: UnG - 201 and UnG - 202. 


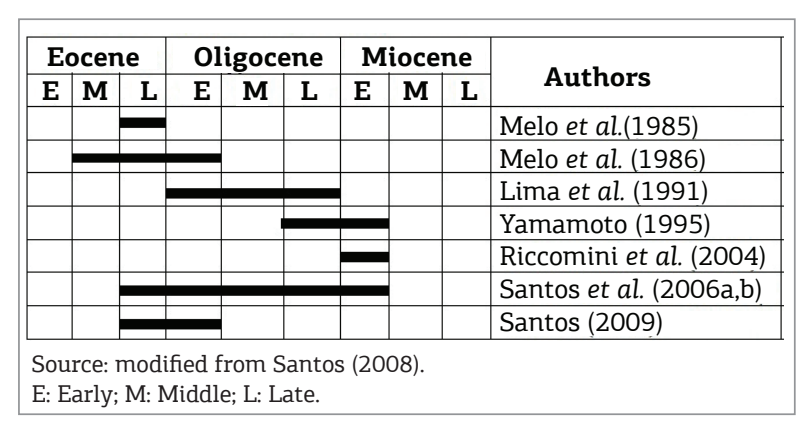

Figure 2. Ages assigned to the Itaquaquecetuba Formation based on palynological data and stratigraphic relationships.

\section{SYSTEMATIC}

In this work, two plant fossils specimens are presented as fragments of impressions, allowing the observation of leaf architecture in some detail and thus to make their generic assignments. The systematic classification adopted is that presented by Takhtajan (1980).

Division Magnoliophyta Cronquist, Takhtajan \& W. Zimmermann 1966

Class Magnoliopsida Takhtajan 1980

Subclass Rosidae Takhtajan 1980

Superorder Rosanae Takhtajan 1967

Order Fabales Bromhead 1838

Family Fabaceae Lindl. 1836

Subfamily Caesalpinoideae D C 1825

Tribe Cercideae Bronn 1822

Genus Baubinia L.

Bauhinia aff. B. divaricata

(Figs. 4A and 4C)

Stratigraphic position: Itaquaquecetuba Formation.

Age: Late Eocene to Miocene

Provenance: Itaquareia 1 Mine, municipality of Itaquaquecetuba, State of São Paulo

Number of the studied specimen: UnG / 3T-153

Description: fragment of bilobed leaf, petiole not preserved. The microphyll measures about $25 \mathrm{~mm}$ long by $35 \mathrm{~mm}$ wide maximum, with an area of $585 \mathrm{~mm}^{2}$, ratio length/width $\max =1 / 1.4$, elliptical or suborbicular, asymmetric, entire margin, lobed apex shape (?) not preserved, reflex apex angle of $340^{\circ}$, cordate leaf base, and reflex base angle of $265^{\circ}$. The median vein presents broken down toward the base. The primary venation is basal actinodromous, composed of three pairs of lateral veins and a median one (total of seven primary veins), starting from two irradiation centers or from a unique one divided in two, during the fossil diagenesis. Primary veins maintain an

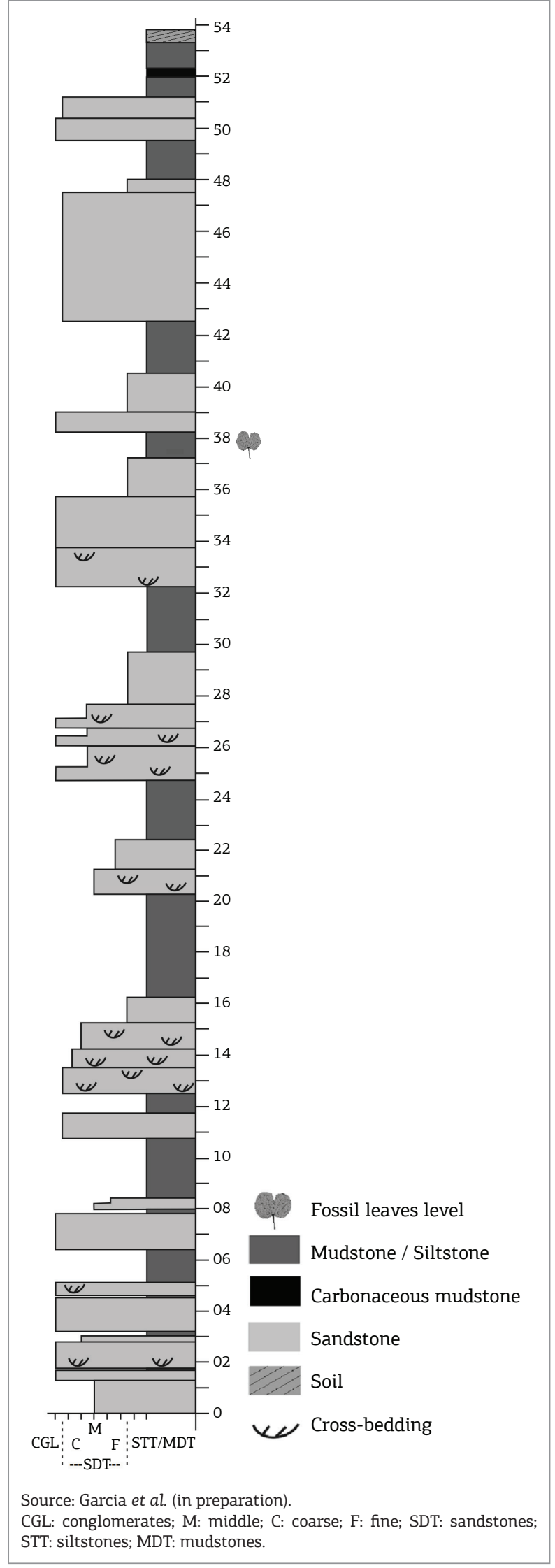

Figure 3. Itaquareia 1 Mine outcrop geological profile, indicating the recovering level of the plant fossils samples. 


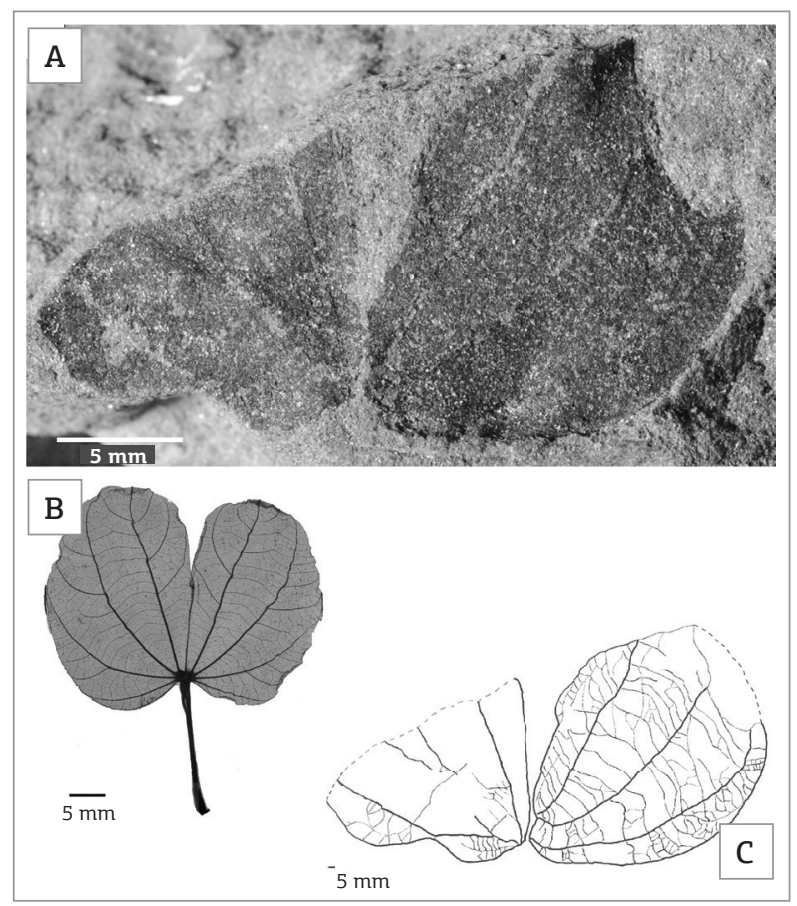

Figure 4. (A) Bauhinia aff. B. divaricata - Specimen UnG - 3T-153. (B) Bauhinia divaricata - clarified leaf blade UnG - 201. (C) Bauhinia aff. B. divaricata Specimen UnG - 3T-153 (drawing).

angle of $20^{\circ}$ to $30^{\circ}$ to each other. The lateral ones converge slightly toward the apex. The secondary veins are gently curved, brochidodromous to eucamptodromous. The tertiary veins emerge from the secondary in right angle and are disposed at obtuse angles after primary midrib. They have a convex to sinuous course delimiting more or less rectangular areoles. Agrophic veins and fimbrial marginal vein are present (Figs. 4A and 4C).

\section{Comparison and discussion}

Since this is only an impression of simple leaf, bilobed or pinnate with leaflets partially fused, entire margin, actinodromous primary venation, secondary tending to a brochidodromous and percurrent tertiary, this specimen is assigned as Fabales, according to Hickey and Wolfe (1975) foliar architecture classification.

Initially, it was compared to Bauhcis Calvillo-Canadell and Cevallos-Ferriz (2002). This Cercideae/Caesalpinoideae fossil genus was erected for Oligocene leaves from Mexico, by presenting leaf architecture similar to the genus Baubinia with other features similar to the genus Cercis. The studied specimen resembles the genus Bauhcis on the following features: single leaf, bilobed, suborbicular, with three primary veins on each side of the midrib (total of seven) arranged at $30^{\circ}$ between each other, tertiary veins emerging from the secondary veins at straight angle and presence of marginal fimbrial vein. However, it differs from Baubcis in the following characters: base shape, secondary venation tending to eucamptodromous, smoother bending of the secondary veins, absence of the intersecondaries, more convex course of the tertiary veins, obtuse angle (not acute) between tertiary and primary one, and rectangular form of the areole instead of pentagonal-triangular (Tab. 1).

It is similar to the genus Baubinia by the presence of the following features: simple leaf, bilobed, oblate shape, with cordate base, palmate actinodromous primary venation with primary veins disposed at $30^{\circ}$, the eucamptodromous to brochidodromous secondary venation of tender course and absence of intersecondaries.

The genus Bauhinia occurs in tropical and warm temperate regions of the world, it has about 350 species of which 200 are native from Brazil (Wunderlin et al. 1987, Marchiori 1997, Vaz \& Tozzi 2005, Wunderlin 2009). Among the five sections that the genus encompasses, the most widely distributed section in the Neotropical region is Pauletia, which has 53 species in Brazil among the 70 existing in the section (Vaz \& Tozzi 2005). The genus extends throughout Brazil, having three typical species of the southern area: $B$. longifolia (Bong) Stend, B. forficata Link and B. divaricata L. This latest is endemic of the south of Brazil, Paraguay, Uruguay and Argentina, according to Alves et al. (2008). The specimen under examination differs from $B$. longifolia due its shorter and wider leaves instead of elliptical/lanceolate shape, cordate leaf base rather than truncated and only 7 primary veins instead of 9 or more (up to 13) (Tab. 1).

It also differs from $B$. forficata by its shorter and wider leaves, cordate foliar base instead of lobed, having only 7 primary veins instead of 9 to 11 , divergence angle of $20^{\circ}-30^{\circ}$ between the primaries, eucamptodromous and brochidodromous secondary venation, marginal fimbriate vein instead of intramarginal (Tab. 1).

The living species that most closely matches the studied specimen is $B$. divaricata. The specimen differs from it by the number of primary veins slightly smaller (seven rather than nine), tertiary veins course sometimes convex, sometimes sinuous, an obtuse angle between tertiary veins and the midrib (rather than straight), and quadrangular areole shape (instead of pentagonal), as shown in Tab. 1.

This is a fragment of a single leaf specimen, presenting some slightly discordant features, that does not allow for undoubted option to B. divaricata (see specimen UnG - 201, Fig. 4B), but also supports the choice of the name $B$. aff. $B$. divaricata. Then, until new collection with better examples will be gotten, it is better to designate it Bauhinia aff. $B$. divaricata. Besides the similarity, the geographic occurrence matching can confirm or rule out this identification. 
Table 1. Comparison between the characteristics of Bauhcis, Bauhinia subrotundifolia, B. divaricata and the studied fossil. The features in bold correspond to those coincident between the studied fossil and the compared species

\begin{tabular}{|c|c|c|c|c|c|c|c|}
\hline & Leaf & Form & Base & Pulvinate & Primary venation & $\begin{array}{l}\text { Angle between the } \\
\text { primary veins }\end{array}$ & $\begin{array}{l}\text { Secondary } \\
\text { venation }\end{array}$ \\
\hline Bauhcis & Simple & $\begin{array}{c}\text { Divided bilobed } \\
\text { oblade }\end{array}$ & $\begin{array}{l}\text { Truncate } \\
\text { lobed }\end{array}$ & Not divided & $\begin{array}{c}\text { Palmate or } \\
\text { actinodromous with } 6 \\
\text { or } 7 \text { veins }\end{array}$ & $30^{\circ}$ & Brochidodromous \\
\hline $\begin{array}{l}\text { Bauhinia } \\
\text { subrotundifolia }\end{array}$ & Simple & $\begin{array}{c}\text { Divided } \\
\text { Bilobed oblate }\end{array}$ & cordate & Not divided & $\begin{array}{c}\text { Palmate or } \\
\text { actinodromous with } 6 \\
\text { or } 7 \text { veins }\end{array}$ & $30^{\circ}$ & Eucamptodromous \\
\hline $\begin{array}{l}\text { Bauhinia. } \\
\text { divaricata }\end{array}$ & Simple & \begin{tabular}{|c|} 
Divided \\
Bilobed oblate
\end{tabular} & cordate & Not divided & $\begin{array}{c}\text { Palmate or } \\
\text { actinodromous with } 9\end{array}$ & $30^{\circ}$ & Eucamptodromous \\
\hline Studied fossil & Simple & \begin{tabular}{|c|} 
Divided \\
Bilobed oblate
\end{tabular} & cordate & $?$ & $\begin{array}{c}\text { Palmate or } \\
\text { actinodromous with } \\
7 \text { veins }\end{array}$ & 20 to $30^{\circ}$ & $\begin{array}{l}\text { Brochidodromous } \\
\text { and } \\
\text { Eucamptodromous }\end{array}$ \\
\hline
\end{tabular}

\begin{tabular}{l|c|c|c|c|c|c}
\hline & $\begin{array}{c}\text { Secondary } \\
\text { vein courses }\end{array}$ & Inter-secondary & Tertiary veins & $\begin{array}{c}\text { Higher order } \\
\text { venation } \\
\text { standard }\end{array}$ & Areole form & $\begin{array}{c}\text { Marginal } \\
\text { vein }\end{array}$ \\
\hline Bauhcis & Abrupt curve & $\begin{array}{c}3 \text { to } 5 \text { veins } \\
\text { Divergent to } 25^{\circ}\end{array}$ & $\begin{array}{c}\text { Straight origin Sinuous course } \\
\text { with acute angle to primary }\end{array}$ & $\begin{array}{c}\text { Random branched } \\
\text { veinlets }-2 \text { or 3 } \\
\text { times }\end{array}$ & $\begin{array}{c}\text { Pentagonal; } \\
\text { triangular to } \\
\text { quadrangular }\end{array}$ & Fimbrial \\
\hline $\begin{array}{l}\text { Bauhinia } \\
\text { subrotundifolia }\end{array}$ & light curve & Absent & $\begin{array}{c}\text { Ortogonal reticulate; Straight } \\
\text { Origin sinuous course with } \\
\text { ortogonal angle to primary }\end{array}$ & $\begin{array}{c}\text { Random branched } \\
\text { veinlets - once }\end{array}$ & $\begin{array}{c}\text { Random and } \\
\text { pentagonal }\end{array}$ & $\begin{array}{c}\text { Intra } \\
\text { marginal }\end{array}$ \\
\hline $\begin{array}{l}\text { Bauhinia. } \\
\text { divaricata }\end{array}$ & light curve & Absent & $\begin{array}{c}\text { Random reticulate; Straight } \\
\text { Origin Straight to convex } \\
\text { course with ortogonal angle } \\
\text { to primary }\end{array}$ & $\begin{array}{c}\text { Random branched } \\
\text { veinlets - } \text { or 3 } \\
\text { times }\end{array}$ & $\begin{array}{c}\text { Random and } \\
\text { pentagonal }\end{array}$ & Fimbrial \\
\hline Studied fossil & light curve & Absent & $\begin{array}{c}\text { Straight Origin Sinuous to } \\
\text { convex course Obtuse angle to } \\
\text { primary }\end{array}$ & Not observed & $\begin{array}{c}\text { Random and } \\
\text { rentagular }\end{array}$ & Fimbrial \\
\hline
\end{tabular}

Source: other species data from Calvillo-Canadell and Cevallos-Ferriz (2002).

\section{Habit and habitat of the genus}

Bauhinia is distributed in southeast and southern areas of Brazil, as deciduous or semi-deciduous plant in the Atlantic rain forest, in savannas and in the altitude semi-deciduous latifoliate forest. It is a heliophyte plant, indifferent to the soil moisture conditions in semi-deciduous forest, typical of alluvial plains or top moist slopes and of rare occurrence in dense primary forest (Wunderlin et al. 1987, Marchiori 1997, Vaz \& Tozzi 2005, Wunderlin 2009).

\section{Phytogeography}

The Caesalpinoideae are probably the most primitive subfamily of Fabaceae, with around 2,800 species which inhabit the tropical and subtropical regions around the world. They are abundant in the Paleotropical Kingdom, especially in Africa. In Brazil, they are more numerous in the north-central and less diverse in the south (Marchiori 1997).

\section{Fossil evidences of fabaceae-caesalpinoideae}

The Fabaceae (Leguminosae) along with Annonaceae, Myrtaceae, Arecaceae are among the typical megathermals angiosperms of the diversification equatorial center (Morley 2000, Morley \& Dick 2003).

\section{Paleobiogeography}

They arose during the Late Cretaceous, when probably there would be easily a reciprocal dispersion of species between South America and Africa, considering the still existing proximity (about $800 \mathrm{~km}$ away, with numerous interspersed volcanic islands). After the Paleocene by vicariance, considerable floristic differentiation settled between the two continents, determining a wide generic differentiation of the Caesalpinoideae.

The genus Bauhinia, native of Brazil, has been placed between the Caesalpinoideae Cercideae. Its high diversity in Brazil suggests this country as its center of origin or dispersion or, at least, leads us to consider this genus having a very old occurrence here.

It has macrofossiliferous record during the Miocene of Loja (Ecuador) (Berry 1929, 1945) and of Potosi (Bolivia) (Berry 1917, 1922a), as well as during the Pliocene of Jancocata (Bolivia) (Berry 1922b). Pollen grains of Bauhinia were detected in palynological analysis of the Quaternary peat bogs of middle valley of the Paraíba do Sul River, in the areas of the Jacareí, Eugênio de Melo and Taubaté municipalities, and also in Quaternary sediments of the Embu Guaçu River valley, State of São Paulo, on a rich and diverse 
palynoflora, typical of moist environment (Garcia et al. 1997, Garcia 1998).

This is the first Paleogene record of the genus in Brazil and perhaps in the South America.

Superorder Myrtanae Takhtajan 1980

Order Myrtales Juss. ex Bercht \& J. Presl 1820

Suborder Myrtineae Takhtajan 1980

Family Melastomataceae Juss. 1789

Tribe Miconiae Palézieu 1899

Genus Leandra Raddi (1820)

Leandra sp.

(Figs. 5A-5C)

Stratigraphical position: Itaquaquecetuba Formation.

Age: Late Eocene-Oligocene to Miocene

Provenance: Itaquareia 1 Mine, municipality of Itaquaquecetuba, State of Sáo Paulo

Number of specimen: UnG / 3T-154.

Description: basal fragment of simple leaf, not preserved petiole, measuring $52 \mathrm{~mm}$ long by $35 \mathrm{~mm}$ of the maximum wide preserved, covering an area greater than 2,000 $\mathrm{mm}^{2}$ (microphyll). Its maximum width, located at the midpoint of the length, is suggestive of an elliptical shape. Not lobed, symmetrical, with marginal petiole attachment, apex not preserved, entire margin and cuneate or straight base of acute angle. The primary venation is suprabasal acrodromous; the two primary lateral veins emerge $-10 \mathrm{~mm}$ above the base, have caliber about $75 \%$ of that one of the midrib, curved and parallel to the margins of the foliar lamina. The first secondary veins have $25 \%$ caliber of that of the midrib. They emerge from this, $3 \mathrm{~mm}$ above the foliar base, and have acrodromous course too. The tertiary veins are opposite percurrent, making an obtuse angle with the midrib and connecting themselves to the lateral primary ones at an acute angle, outlining a straight or convex course. They also emerge from the lateral primary veins toward the intramarginal secondary ones in straight to convex course. This leaf shows fimbrial veins and blade of cartaceous texture (Figs. 5A-C and E).

Comparison and discussion: The Melastomataceae leaves are easily recognized among the eudicotyledonous because they are, in general, of entire or frizzy undulate margin, typically petiolate, with primary lateral veins running in parallel to the leaf margin, from the base to the apex (acrodromous venation). This type of venation, synapomorphic in the Melastomataceae, is rare among other angiosperms and never as persistent as among them (Hickey 1973, Renner 1993).

Comparing the analyzed specimen to the Bertolonia sp., the Melastomataceae assigned by Fittipaldi et al. (1989) and Fittipaldi (1990), in the Itaquaquecetuba paleoflora, it is possible to distinguish it by presenting suprabasal acrodromous venation, supported by three primary veins and not five basal (as in that genus), leaf size larger, narrow elliptical shape (rather than wide) and cuneate base (instead of convex). Moreover, the specimen is also distinguished from the genera Tibouchina and Miconia due to the suprabasal acrodromous venation.

The studied specimen compares to the genus Leandra (another Melastomataceae) on the following features: elliptical cartaceous, glabra leaf, entire or undulate frizzy margin, with three primary suprabasal acrodromous veins; the secondary venation is also acrodromous and has emergence point position below the lateral primary one; the opposite percurrent tertiary veins are of a straight to a convex course and there is a fimbrial vein.

Within the genus Leandra, the species that have suprabasal acrodromous veins are: L. acutiflora, L. collina, $L$.
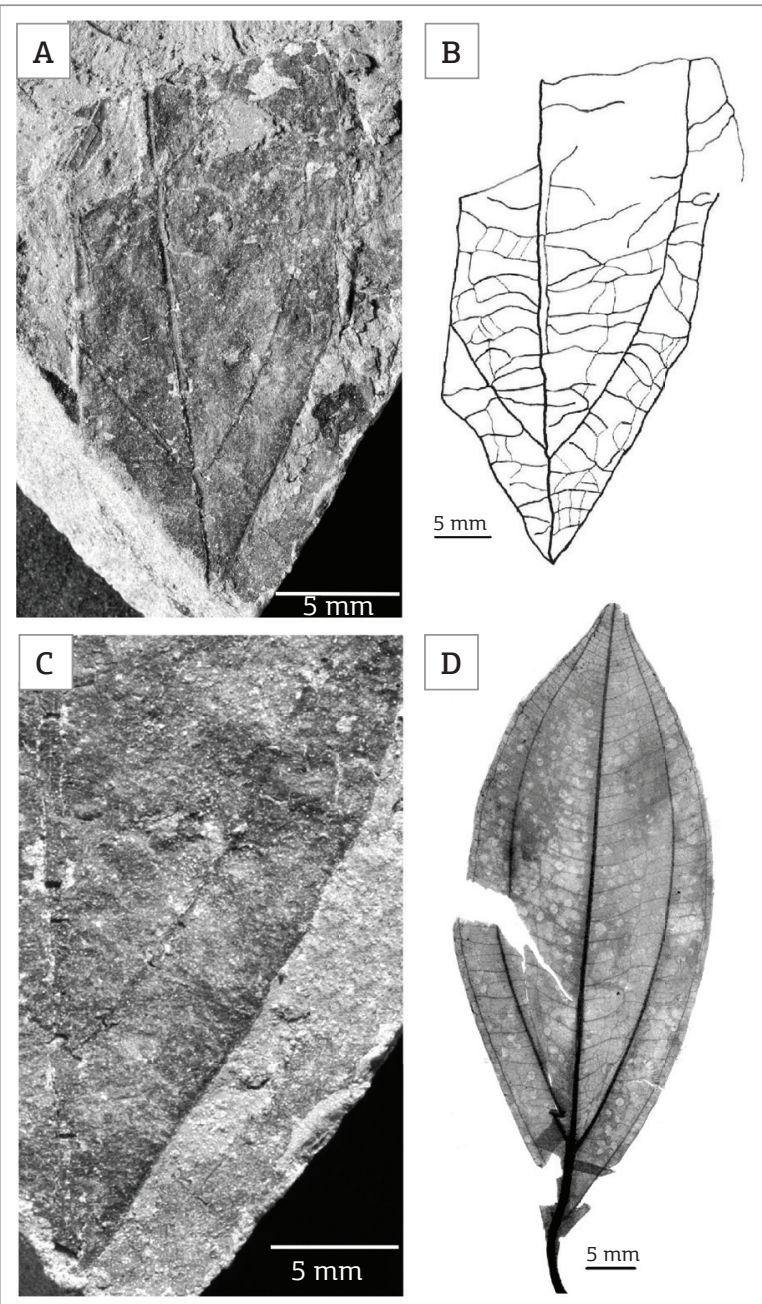

Figure 5. (A) Leandra sp. - Specimen UnG 3T-154. (B) Leandra sp. - Specimen UnG 3T-154 (Drawing).

(C) Detail of the basal portion of the same specimen.

(D) Leandra acutiflora clarified blade Leaf UnG - 202. 
fallax, L. hirtella, L. laxa, L. melastomoides, L. ribesiaeflora and L.quinquedentata, according to studies carried out by Rodrigues-Lima and Affonso (2010), in the Serra do Mar State Park. The species L. mattosii, restricted to the region of Salesópolis, State of São Paulo, also has this feature as described by Baumgratz and D'El Rei Souza (2005).

In Tab. 2, it can be seen the comparison between the features of the studied specimen and those of the species most like. It appears that the species $L$. collina, L. fallax, $L$. laxa, L. mattosii, L. melastomatoides, L. quinquedentata and $L$. ribesiaeflora are discarded because they have basal outer pair of veins, among other different features. L. hirtella has oval shape, entire and ciliated margin, and hair on midrib.

There is a close similarity of leaf architecture with Leandra acutiflora (Tab. 2), when compared with the clarified specimen UnG - 202 (Fig. 5D). However, being not possible to establish better affinity with this or that species and due to the scarcity of material, it is suitable only to designate the specimen as Leandra sp.

Habit and habitat of the genus: the genus Leandra, consisting mainly of climbing forms, sub decumbent shrubs or small trees from the edge of the forest and grassland regions, appears associated with Miconia and Tibouchina in the Atlantic forest.

Phytogeography: the Melastomataceae are a pantropical family of 166 genera and 4,200 - 4,500 species. It is remarkable the concentration of their species in the New World, where there are 2,950 species. The genus Leandra is one of the largest genera in the Melastomataceae, appearing in tropical and subtropical America (Renner 1993, Reginato \& Goldenberg 2012). It is distributed from Mexico and Antilles toward Argentina, being very diverse in southeastern Brazil (Cogniaux 1886, 1891, Renner 1993, Marchiori \& Sobral 1997, Baumgratz \& D’El Rei Souza 2005). In the coastal region, in the Serra do Mar and the first plateau of the Paraná State, seven species of Leandraria section were identified (Camargo \& Goldenberg 2007).

Melastomataceae fossil evidence: it is known that fossil pollen grains in this family are difficult to identify, due their similarity to others of the Order Myrtales. However, some of them, considered the probable oldest records of the family, occur in the Paleocene of Colombia (van der Hammen \& García de Mutis 1966); there are also occurrences during the Miocene and Pliocene of Costa Rica and

Table 2. Some Leandra species descriptive data according to Baumgratz and D’El Rei Souza (2005), Camargo et al. (2009) and Rodrigues-Lima and Affonso (2010), in comparison with the Itaq uaquecetuba Formation specimen

\begin{tabular}{|c|c|c|c|c|c|}
\hline \multicolumn{6}{|c|}{ Some species of the genus Leandra Raddi in comparison with fossil specimen } \\
\hline Foliar features & L. acutiflora & L. collina & L. fallax & L. hirtella & L. laxa \\
\hline Leaf organization & Simple & Simple & Simple & Simple & Simple \\
\hline Petiole attachment & $\begin{array}{c}\text { Marginal } \\
0.5-3.2 \mathrm{~cm}\end{array}$ & $\begin{array}{c}\text { Marginal } \\
1.0-2.0 \mathrm{~cm}\end{array}$ & $\begin{array}{c}\text { Marginal } \\
1.0-2.6 \mathrm{~cm}\end{array}$ & $\begin{array}{c}\text { Marginal } \\
1.0-4.0 \mathrm{~cm}\end{array}$ & $\begin{array}{c}\text { Marginal } \\
0.6-2.2 \mathrm{~cm}\end{array}$ \\
\hline Laminar size $(\mathrm{cm})$ & $\begin{array}{l}\text { L. } 5.0-12.0 \\
\text { W. } 1.5-5.0\end{array}$ & $\begin{array}{l}\text { L. } 5.0-8.0 \\
\text { W. } 1.3-2.0\end{array}$ & $\begin{array}{l}\text { L. } 7.5-12.0 \\
\text { W. } 2.0-4.0\end{array}$ & $\begin{array}{l}\text { L. } 4.2-15.0 \\
\text { W. } 1.5-4.5\end{array}$ & $\begin{array}{l}\text { L. } 5.0-11.5 \\
\text { W. } 1.8-4.2\end{array}$ \\
\hline Foliar texture & Membranaceous & Coriaceous & Cartaceous & Membranaceous & Membranaceous \\
\hline Laminar shape & $\begin{array}{l}\text { Elliptic to oblong- } \\
\text { elliptic }\end{array}$ & Oblong & Ovate & Ovate & Ovate \\
\hline Margin type & Entire & $\begin{array}{l}\text { Crenate } \\
\text { and ciliate }\end{array}$ & Entire & Entire or ciliate & $\begin{array}{c}\text { Entire to slightly } \\
\text { dentate }\end{array}$ \\
\hline Apex shape & Acuminate & Acuminate & Acuminate & Acuminate & Acuminate \\
\hline Base shape & Decurrent & Cuneate & Cuneate & Cuneate & Convex to cuneate \\
\hline $\mathrm{N}^{\circ}$ of primary veins & $\begin{array}{c}3+2 \text { suprabasal; } \\
\text { internal pair emerging } \\
\text { at } 0.9-2.0 \mathrm{~cm} \text { from } \\
\text { the base, external } \\
\text { pair emerging at } 0.4- \\
0.7 \mathrm{~cm} \text { from the base. }\end{array}$ & $\begin{array}{c}5 \text { suprabasal, } \\
\text { internal pair } \\
\text { emerging at } 0.1 \text { - } \\
0.2 \mathrm{~cm} \text { from the base } \\
\text { and basal external } \\
\text { pair. }\end{array}$ & $\begin{array}{c}5+2 \text { suprabasal } \\
\text { internal pair } \\
\text { emerging at } 0.3- \\
0.8 \mathrm{~cm} \text { from the base, } \\
\text { intermediary and } \\
\text { basal external pairs. }\end{array}$ & $\begin{array}{c}5 \text { suprabasal, internal } \\
\text { pair emerging at } \\
0.9-2.2 \mathrm{~cm} \text { from the } \\
\text { base, external pair } \\
\text { emerging at } 0.1 \text { - } \\
0.8 \mathrm{~cm} \text { from the base. }\end{array}$ & $\begin{array}{c}5 \text { suprabasal, internal } \\
\text { pair emerging at } 0.9- \\
2.2 \mathrm{~cm} \text { from the base, } \\
\text { basal external pair. }\end{array}$ \\
\hline Adaxial face & Glabrous & Sparse- setosus & $\begin{array}{c}\text { Moderately } \\
\text { strigosus. } \\
\text { Simple trichomes, } \\
0.6-1.0 \mathrm{~mm} \\
\text { (length), erect. }\end{array}$ & $\begin{array}{l}\text { Hirsute only on the } \\
\text { midrib. }\end{array}$ & $\begin{array}{c}\text { Moderately } \\
\text { strigosus. } \\
\text { Simple trichomes, } \\
0.3-0.5 \mathrm{~mm} \\
\text { (length). }\end{array}$ \\
\hline Abaxial face & $\begin{array}{c}\text { Glabrous. } \\
\text { Simple trichomes at } \\
\text { the base of primary } \\
\text { veins. Domatia } \\
\text { present. }\end{array}$ & $\begin{array}{c}\text { Densely } \\
\text { pubescent only on } \\
\text { the primary veins } \\
\text { and sparsely starry } \\
\text { on the others. }\end{array}$ & $\begin{array}{l}\text { Densely hirsute. } \\
\text { Simple tricomes, } \\
0.6-0.8 \mathrm{~mm} \\
\text { (length), coiled. }\end{array}$ & $\begin{array}{c}\text { Scarcely hirsute } \\
\text { on the primary } \\
\text { veins. }\end{array}$ & $\begin{array}{c}\text { Moderate to densely } \\
\text { pubescent. } \\
\text { Simple trichomes, } \\
0.3-0.5 \mathrm{~mm} \\
\text { (length), scarcely } \\
\text { starry-furfureous. }\end{array}$ \\
\hline
\end{tabular}


Table 2. Continuation

\begin{tabular}{|c|c|c|c|c|c|}
\hline \multicolumn{6}{|c|}{ Some species of the genus Leandra Raddi in comparison with fossil specimen } \\
\hline Foliar features & L. mattosii & L. melastomoides & L. quinquedentata & L. ribesiaeflora & Fossil specimen \\
\hline Leaf organization & Simple & Simple & Simple & Simple & Simple \\
\hline Petiole attachment & $\begin{array}{c}\text { Marginal } \\
1.6-3.5 \mathrm{~cm}\end{array}$ & $\begin{array}{c}\text { Marginal } \\
0.3-0.5 \mathrm{~cm}\end{array}$ & $\begin{array}{c}\text { Marginal } \\
0.5-2.3 \mathrm{~cm}\end{array}$ & $\begin{array}{c}\text { Marginal } \\
0.3-1.4 \mathrm{~cm}\end{array}$ & $\begin{array}{c}\text { Marginal } \\
0.3-1.4 \mathrm{~cm}\end{array}$ \\
\hline Laminar size $(\mathrm{cm})$ & $\begin{array}{l}\text { L. } 6.8-12.6 \\
\text { W. } 2.8-5.0\end{array}$ & $\begin{array}{l}\text { L. } 10.7-27.0 \\
\text { W. } 3.2-7.5\end{array}$ & $\begin{array}{c}\text { L. } 13.5 \\
\text { W. } 1.2-4.2\end{array}$ & $\begin{array}{l}\text { L. } 2.3-7.0 \\
\text { W. } 1.0-2.5\end{array}$ & $\begin{array}{l}\text { L. } \sim 5.2 \\
\text { W. } \sim 3.5\end{array}$ \\
\hline Foliar texture & Membranaceous & Membranaceous & Coriaceous & Coriaceous & Membranaceous \\
\hline Laminar shape & Elliptic or ovate & Ovate & $\begin{array}{l}\text { Elliptic to oblong- } \\
\text { elliptic }\end{array}$ & Ovate & Elliptic \\
\hline Margin type & $\begin{array}{c}\text { Serrate to ciliate, } \\
\text { sometimes revolute }\end{array}$ & $\begin{array}{l}\text { Crenate } \\
\text { and ciliate }\end{array}$ & Revolute & Entire or ciliate & Entire \\
\hline Apex shape & Acuminate & Acuminate & Acuminate & Acuminate & Not preserved \\
\hline Base shape & Decurrent & Cuneate & Convex to cuneate & Slightly cuneate & Cuneate \\
\hline $\mathrm{N}^{\circ}$ of primary veins & $\begin{array}{c}5 \text { acrodromous veins, } \\
1.6 \text { mm suprabasal } \\
\text { internal pair } \\
\text { emerging at } 0.5-0.7 \\
\text { cm from the base, } \\
\text { basal external pair. }\end{array}$ & $\begin{array}{c}5 \text { suprabasal, } \\
\text { internal pair } \\
\text { emerging at } 1.2- \\
3.0 \mathrm{~cm} \text { from the } \\
\text { base, basal external } \\
\text { pair. }\end{array}$ & $\begin{array}{c}3+2 \text { basal, internal } \\
\text { pair emerging at } 0.5 \\
-0.7 \mathrm{~cm} \text { from the } \\
\text { base, basal external } \\
\text { pair. }\end{array}$ & $\begin{array}{c}5 \text { suprabasal, } \\
\text { internal pair } \\
\text { emerging at } 0.4- \\
0.7 \mathrm{~cm} \text { from the } \\
\text { base, basal external } \\
\text { pair. }\end{array}$ & 5 suprabasal \\
\hline Adaxial face & $\begin{array}{c}\text { Moderately } \\
\text { glandule-granular. } \\
\text { Deciduous } \\
\text { trichomes or not. }\end{array}$ & $\begin{array}{l}\text { Setosus on the } \\
\text { primary veins and } \\
\text { sparse-strigosus } \\
\text { on the others. }\end{array}$ & $\begin{array}{l}\text { Glabrous. } \\
\text { Rare trichomes, } \\
\text { scarcely starry- } \\
\text { furfureous. }\end{array}$ & Sparse-strigosus. & Glabrous \\
\hline Abaxial face & $\begin{array}{c}\text { scarcely to } \\
\text { moderately hirsute- } \\
\text { setosus. } \\
\text { Deciduos } \\
\text { trichomes or not. }\end{array}$ & Setosus. & $\begin{array}{c}\text { Furfureous. } \\
\text { Scarcely simple } \\
\text { trichomes on the } \\
\text { base of the primary } \\
\text { veins. } \\
\text { Domatia present. }\end{array}$ & $\begin{array}{l}\text { Sparse-hispid } \\
\text { and starry on the } \\
\text { primary veins and } \\
\text { sparse-starry on the } \\
\text { others. }\end{array}$ & Glabrous. \\
\hline
\end{tabular}

Panama (Graham 1987, 1991). During the Late Eocene to Oligocene of Brazil (Itaquaquecetuba Formation, São Paulo basin), Santos (2009) recorded the presence of Melastomataceae pollen grains of possible affinity with the Miconia.

The plant macrofossils assigned to the Melastomataceae have more secure botanical affinities than the pollen grains, being present since the South American Paleogene. Melastomataceae leaves appear in the Eocene of Colombia, in Antioquia (Huertas 1977). In Fonseca, Minas Gerais State (Late Middle - Early Late Eocene of Brazil), Duarte (1956) recorded plant fossils of Miconia and Tibouchina. In the Oligocene strata of Brazil, there are records of Bertolonia in the Itaquaquecetuba Formation (Fittipaldi et al. 1989, Fittipaldi 1990).

The Neogene macrofossiliferous registers of South America for Melastomataceae are in the Miocene of Brazil, assigned to the Meriania genus of the Pirabas Formation in Capanema, Pará State (Duarte 2004), and to the Tibouchina genus of the Pindamonhangaba Formation, Taubaté basin, São Paulo State (Tufano 2009). In the Miocene strata of Chile, Miconia was recorded (Hinojosa 2003). In the Miocene of Argentina, Tibouchina was recorded in San Jose de Tucumán (Anzótegui \& Herbst 2004, Anzótegui 2004) and in El Morterito, Catamarca (Anzótegui et al. 2006). In the Brazilian Pliocene strata, Huberia and Miconia were recorded in Alagoinhas (Hollick \& Berry 1924) and Pedrão, Bahia State (Berry 1935); Tibouchina was registered in Pedrão, Bahia State (Berry 1935), and Vargem Grande do Sul, São Paulo State (Mezzalira 1964, 1966, Duarte \& Rezende-Martins 1983, 1985). It is worth mentioning that Melastomataceae leaves were also identified in tertiary deposits of the Seymour Island, Antarctic (Dusén 1908).

Paleobiogeography: Renner (1993), considering all the available fossil evidences, suggested the Eastern Gondwana (Antarctica + Australia + New Guinea) as a possible place of origin of the Melastomataceae, because the family displays much greater diversity in that region; the plesiomorphic groups (Kibessieae and Astronieae) occur in the Malaysian region; there is a fossil documentary in Antarctica and there are three tribes that spread themselves from Southeast Asia to South America. The Miconieae tribe (containing Leandra) appears in the regions described above and absent in Africa. Therefore, that author assumed that this tribe has originated in Eastern Gondwana and migrated to the West, across Antarctica, when Africa was already separated from the area.

So, according to Renner (1993), the biogeography, the fossil history and the phylogeny of the Melastomataceae 
suggest an origin in Eastern Gondwana (Malaysian region). For the author, India — suggested by Nayar (1972) as the point of origin of the Melastomataceae - , should be excluded of this possibility because presenting apomorphic species.

Raven and Axelrod (1974) suggested that the Melastomataceae originated in Western Gondwana.

After a comprehensive assessment of the biogeography and of the fossil record of the tropical plants, within a framework of tectonics plate, Morley (2000) described three main diversification centers of megathermal angiosperms during the CretaceousPaleogene interval: the first center was crossing the northern mid -latitudes (Laurasia) comprising the Actinidiaceae, Icacinaceae, Rutaceae, Menispermaceae, Theaceae and Zingiberaceae families; the second one would be an equatorial center (Western Gondwana) with, among others, the Annonaceae, Fabaceae, Myrtaceae and Arecaceae families, and the third center would be in the southern mid-latitudes (Austral Gondwana) involving very old families, such as Chloranthaceae, Winteraceae and Proteaceae. For Morley (2000), the Melastomataceae constituted an important family of rainforests, with great diversity in the Neotropical area, during the Paleogene, although their macrofossil documentary is poor at low latitudes, as also is their palynological documentary, this mainly due to difficulties in distinguishing them from those of Combretaceae.

Morley and Dick (2003), calibrating the molecular clock and considering the fossil documentary, based on Melastomataceae well-established, dated dispersion routes and considering their great diversity in South America, concluded that it is a family having a history essentially within the equatorial zone, with occasional episodes of spread for the boreo-tropical province (Northern Hemisphere), during times of globally hot climate, especially during the Late Paleocene to Early Eocene thermal maximum (Fig. 6).

They also concluded that the dispersion routes of the Melastomataceae and the reason for their Gondwanian plant fossils poverty would be the key-considerations to be done in the next reconstructions of the Pantropical rainforests taxa biogeography history.

\section{DISCUSSION AND CONCLUSIONS}

From the sedimentological point of view, the Itaquaquecetuba Formation consists of a coarse-grained clastic sequence, indicative of short transportation or proximity of the source area, with trough and tabular cross-bedding of braided river system, associated with alluvial fans. However, it contains silty clay levels, sometimes sandy colored greenish gray, rich in organic matter, with cementation by marcasite frequently noted as indicative of casual reducing environment. For this formation, a deposition system in alluvial fans associated to meandering fluvial facies with ribbon-type channels, i.e. fixed and narrow channels, was recently suggested.

The chaotic arrangement of leaves in the taphofloristic assemblage suggests deposition in a quiet environment, while the sparse distribution and the fragmentation of many leaf elements suggest fast transport for some distance since the source area to the site of deposition (biostratinomic implications).

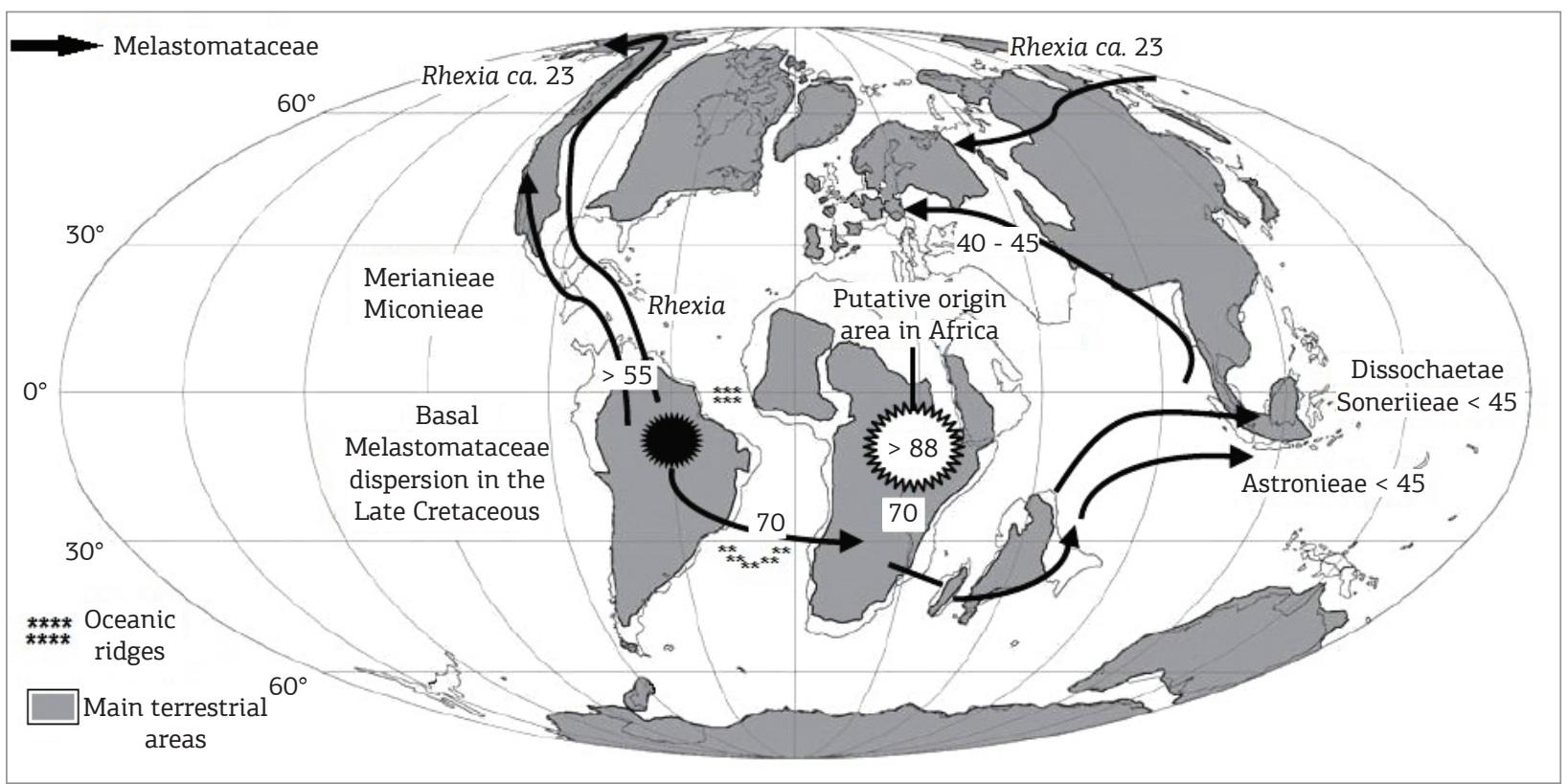

Figure 6. Map of Melastomataceae dispersion during Late Cretaceous - Early Paleocene, as Morley and Dick (2003) conceptions, with modifications. 
From the paleobotanical standpoint, the Itaquaquecetuba Formation presents a diversified paleoflora of Bryophytes, Filicophytes, Lauraceae, Araceae, Alismataceae, Myrtaceae, Vochysiaceae, Melastomataceae, Salicaceae, Malpighiaceae, Elaeocarpaceae, Fabaceae (Mimosoideae, Faboideae and Caesalpinoideae), Rhamnaceae, Malvaceae, Anacardiaceae, Sapindaceae, Rutaceae, Rubiaceae, and Aquifoliaceae, based on stems, leaves and fruits macrofossils suggestive of rain tropical climate. All living genera related to the identified fossil forms are typical mainly from the Atlantic hillside rainforest and from the semi-deciduous latifoliated forest in altitude.

The pantropical genus Baubinia occurs in tropical and warm temperate regions of the world, reaching about 350 species of which 200 are native from Brazil. Its high diversity in the country suggests that its center of origin or dispersion, or at least its occurrence here, is very ancient. However, this is the first Paleogene record in Brazil and perhaps in South America.

Melastomataceae were detected in the fossil record of the lithostratigraphic unit, as Miconia woods (Suguio 1971) and Bertolonia leaves (Fittipaldi et al.1989, Fittipaldi 1990). This is the third fossil record of the family in the formation and the first of the genus Leandra. The presence of these three genera in Late Eocene/Oligocene of the São Paulo basin, and also of Tibouchina in the Middle Late Eocene of the Fonseca basin, indicates a reasonable diversity of the Melastomataceae in southeastern Brazil, since the Paleogene. Thus, the record of another genus of the family in the region might reinforce the idea of its origin as being in Western Gondwana.

The typical habits and habitats of the genera Baubinia and Leandra, herein described, corroborate the landscape reconstitution provided by the sedimentology and by the floristic components previously detected.

\section{ACKNOWLEDGMENTS}

The authors wish to thank Prof. Dr. A.R. Saad, Coordinator of MAG (Geoenvironmental Analysis MD Program) of the Guarulhos University (UnG), for his help in clearing up the São Paulo basin geological data, Prof. Élcio M. de Mello, Photograph Lab, for his support in the preparation of the photographs used in this paper, as well as the Biologist Patricia Rosa, Technician of the Laboratory of Geosciences (UnG) for her assistance in the preparation of the clarified leaf blades, to Isa Mendes for the translation of this paper, to the Herbarium of the Horto Florestal State Park of the Secretaria de Meio Ambiente of the State of São Paulo, for providing herbarium specimens of current species for comparison, to M.Sc. Fabio Casado, for his assistance in preparation of figures, and to the anonymous reviewers, who patiently examined the manuscript, contributing to its improvement.

\section{REFERENCES}

Alves E.U., Nascimento C.D.L., Bruno R.L.A., Alves A.U., Braga Junior J.M., Cardoso E.A., Galindo E.A., Silva K.B. 2008. Germinação e vigor de sementes de Bauhinia divaricata L. Ciência Rural, 38(4):960-966.

Anzótegui L.M. 2004. Megaflora de la Formación Chiquimil (Mioceno Superior), en los valles de Santa Maria y Villavil, provincias de Catamarca y Tucumán, Argentina. Ameghiniana, 41(3):303-314.

Anzótegui L.M. \& Herbst R. 2004. Megaflora (hojas y frutos) de la Formación San José (Mioceno Medio) en río Seco, departamento Santa María, provincia de Catamarca, Argentina. Ameghiniana, 41(3):423-436

Anzótegui L.M., Garralla S.S., Martinez Y.Y., Horn Y. 2006. Representatividad e importancia de Fabaceae en el Neógeno de Argentina. In: 9o Congreso Argentino de Paleontología y Biostratigrafía, Anais..., v. 1, p. 31.

Baumgratz J.F.A. \& D’El Rei Souza M.L. 2005. Novas espécies de Leandra Raddi (Melastomataceae) para o Estado de São Paulo, Brasil. Acta Botanica Brasilica, 19(3):561-566.

Bedani E.F. \& Saad A.R. 2009. Paisagem natural paleógena da bacia sedimentar de São Paulo no Município de Guarulhos, Estado de São Paulo. Revista Geociências, 28(4):363-376.

Berry E.W. 1917. Fossil plants from Bolivia and their bearing upon the age of uplift of the eastern Andes. Proceeding of the United States Natural Museum, 54:103-164.
Berry E.W. 1922a. Pliocene fossil plants from the eastern Bolivia. Johns Hopkins University Studies in Geology Press, 4:145-203.

Berry E.W. 1922b. Late Tertiary plants from Jancocata, Bolivia. In: Contributions to the Paleobotany of Peru, Bolivia and Chile. Johns Hopkins University Studies in Geology Press, 4:205-221.

Berry E.W. 1929. The fossil flora of Loja Basin in Southern Ecuador. Johns Hopkins University Studies in Geology Press, 10:79-136.

Berry E.W. 1935. Tertiary plants from Brazil. Proceedings of the American Philosophical Society, 75(7):565-590.

Berry E.W. 1945. Fossil floras from southern Ecuador. Johns Hopkins University Studies in Geology Press, 14:93-150.

Camargo E.A. \& Goldenberg R. 2007. O gênero Leandra, seção Leandraria (Melastomataceae) no Paraná. Iheringia - Série Botânica, 62:105-113

Camargo E.A., Souza C.M.F., Caddah M.K., Goldenberg R. 2009. O gênero Leandra, Seções Carassanae, Chaetodon, Niangae, Oxymeris e Secundiflorae (Melastomataceae) no Estado do Paraná. Rodriguésia, 60(3):595-631

Campos J.E., Ferreira L.M.R., Albuquerque Filho J.L., Kakazu M.C. 2002. Síntese do conhecimento hidrogeológico da Bacia Sedimentar de São Paulo. In: ABAS, $12^{\circ}$ Congresso Brasileiro de Águas Subterrâneas, Anais, 14 p. 
Calvillo-Canadell L. \& Cevallos- Ferriz S.R.S. 2002. Bauhcis moranii gen. et sp. nov. (Cercideae, Caesalpineae) an Oligocene plant from Tepexi de Rodriguez, Puebla, Mex., with leaf architecture similar to Bauhinia and Cercis. Review of Palaeobotany and Palynology. 122:171-184.

Cogniaux A. 1886. Leandra Raddi (Melastomataceae). In: Martius C.F.P. \& Eichler A.G. (eds.). Flora Brasiliensis. Lipsiae Frid. Fleischer, 14(4):66-209.

Cogniaux A. 1891. Leandra Raddi (Melastomataceae). In: De Candolle A. \& De Candolle C. Monographiae Phanerogamarum. v. 7. Paris, G. Masson, p. 615-696.

Coimbra A.M., Riccomini C., Melo M.S. 1983. A Formação Itaquaquecetuba: evidências de tectonismo no quaternário paulista. In: SBG, 4 º Simpósio Regional de Geologia, Atas, p. 253-266.

Duarte L. 1956. Melastomataceae fósseis da bacia terciária de Fonseca, Minas Gerais. DNPM. Boletin da Divisão de Geologia e Mineralogia, 161:7-32

Duarte L. 2004. Paleoflórula. In: Rossetti D. \& Goes A.M. (eds.). O Neógeno da Amazônia Oriental. Belém, Museu Paraense Emilio Goeldi, Coleção Friedrich Katzer, p. 169-196.

Duarte L. \& Rezende-Martins A.F.P. 1983. Contribuição ao conhecimento da flora cenozóica do Brasil, Jazigo Vargem Grande do Sul, SP. Anais da Academia Brasileira de Ciências, 55(1):109-121.

Duarte L. \& Rezende-Martins A.F.P. 1985. Contribuição ao conhecimento da flora cenozóica do Brasil. Jazigo Vargem Grande do Sul, SP. Série Taubaté II. Coletânea de Trabalhos Paleontológicos, Série Geologia, 27. Seção de Paleontologia e Estratigrafia, 2:565-571.

Dutra T. \& Stranz A. 2002. Clarificação e diafanização de folhas. In: Dutra T.L. (ed.). Técnicas e procedimentos de trabalhos com fósseis e formas modernas comparativas. São Leopoldo, Editora da Unisinos, p. 27-29.

Dusén P. 1908. Über die tertiäre Flora der Seymour-Insel (Wissenschaftliche Ergebnisse der Schwedischen SüdpolarExpedition, 1901-1903, v. 3, n. 3). Stockholm: Lithographisches Institut des Generalstabs, p. 1-27.

Fittipaldi F.C. 1990. Vegetais fósseis da Formação Itaquaquecetuba: Cenozóico, Bacia de São Paulo. PhD Thesis, Instituto de Geociências, Universidade de São Paulo, São Paulo, 146 p.

Fittipaldi F.C. 2002. Primeira ocorrência de briófitas na Bacia de São Paulo (Cenozóico). Revista do Instituto Geológico, 23(2):19-22.

Fittipaldi F.C. \& Simões M.G. 1989. Estado atual do conhecimento sobre a paleontologia da Bacia de São Paulo. In: IGc - USP e SBG, $1^{\circ}$ Workshop “Geologia da Bacia de São Paulo”, p. 27-34.

Fittipaldi F.C. \& Simões M.G. 1990. Problemas conceituais e metodológicos das interpretações paleoclimáticas com base em vegetais fósseis (o exemplo da Formação Itaquaquecetuba/ Cenozóico, bacia de São Paulo). In: 7a Reunião de Paleobotânicos e Palinólogos, Paleobotânica Latino-americana (Circular Informativa da ALPP), Resumos, v. 9, n. 1, p. 17-18.

Fittipaldi F.C., Simões M.G., Giulietti A.M., Pirani J.R. 1989. Fossil plants from the Itaquaquecetuba Formation (Cenozoic of the São Paulo Basin) and their possible paleoclimatic significance. Boletim IG-USP: Publicação Especial, 7:183-203.

Foster A.S. 1952. Foliar venation in angiosperms from an ontogenetic view point. American Journal of Botany, 39:752-766.

Garcia M.J. 1998. Palinologia de turfeiras quaternárias do médio vale do rio Paraíba do Sul, Estado de São Paulo, Brasil. Parte 2: Gymnospermae e Magnoliophyta. Geociências - Revista da Universidade Guarulhos, 3:148-165.
Garcia M.J., Motta J.F.M., Mello I.S.C., Cabral Junior M., Saad A.R., Bertozzi-Silva V. 1997. Considerações preliminares sobre a palinoflora quaternária dos depósitos sedimentares do vale do rio Embu-Guaçu, Estado de São Paulo, Brasil. SP.2 . Geociências - Revista da Universidade Guarulhos, (nº especial):241. Resumo.

Garcia M.J., Quindici M.Z., Saad A.R., Mendonça-Filho J., Antonioli L., Dino R., Bistrichi C.A., Casado F., Menezes J.B. Palinofácies da Formação Itaquaquecetuba, Paleógeno da bacia de São Paulo. (in preparation).

Graham A. 1987. Miocene communities and paleoenvironments of southern Costa Rica. American Journal of Botany, 74:1501-1518.

Graham A. 1991. Studies in neotropical paleobotany, IX. The Pliocene communities of Panama. Annals of the Missouri Botanical Garden, 78:201-223.

Hickey J.L. 1973. Classification of architecture of dicotyledonous leaves. American Journal of Botany, 60:17-33.

Hickey L.J. \& Wolfe J.A. 1975. The bases of angiosperm phylogeny: vegetative morphology. Annals of the Missouri Botanical Garden, 62:538-589

Hinojosa L.F. 2003. Fisionomía foliar y clima de las paleofloras mixtas del Terciario de Sudamérica. MS Dissertation, Facultad de Ciencias, Universidad de Chile, Santiago, $174 \mathrm{p}$

Hollick C.A. \& Berry E.W. 1924. A late tertiary flora from Bahia, Brazil. Baltimore, The Johns Hopkins University Studies in Geology, n. 5, p. 11-136.

Huertas G.G. 1977. Una melastomatacea fosil del Terciario Carbonifero de Antioquia (Eoceno). Caldasia, 12(56):35-39.

Lima M.R., Melo M.S., Coimbra A.M. 1991. Palinologia de sedimentos da bacia de São Paulo, Brasil. Revista do Instituto Geológico, 12(1-2):7-20.

Marchiori J.N.C. 1997. Dendrologia das angiospermas: das magnoliáceas às flacurtiáceas. Santa Maria: Editora da UFSM, 271 p.

Marchiori J.N.C. \& Sobral M. 1997. Dendrologia das angiospermas: Myrtales. Santa Maria, Editora da UFSM, 304 p.

Melo M.S., Caetano S.L.V., Coimbra A.M. 1986. Tectônica e sedimentação na área das bacias de São Paulo e Taubaté. In: $34^{\circ}$ Congresso Brasileiro de Geologia, Anais, p. 321-336.

Melo M.S., Vincens A., Tucholka P. 1985. Contribuição à cronologia da Formação Itaquaquecetuba, SP. Anais da Academia Brasileira de Ciências, 57(2):175-181.

Mezzalira S. 1962 Novas ocorrências de vegetais fósseis cenozóicos no Estado de São Paulo. Revista do Instituto Geográfico e Geológico (1961 - 1962), 15:73-91

Mezzalira S. 1966. Os fósseis do Estado de São Paulo. Boletim do Instituto Geográfico e Geológico, 45:1-132.

Morley R.J. 2000. Origin and evolution of tropical rain forests. West Sussex, John Wiley \& Sons, 362 p.

Morley R.J. \& Dick C.W. 2003. Missing fossils, molecular clocks, and the origin of the Melastomataceae. American Journal of Botany, 90:1638-1644

Nayar M.P. 1972. Centers of development and patterns of distribution of the family Melastomataceae in Indo-Malesia. Bulletin Botanical Survey, 14:1-12

Raddi G. 1820. Quaranta piante nuove del Brasile raccolte e descrite. Memorie di Matematica e di Fisica della Società Italiana delle Scienze Residente in Modena, 18:382-414.

Raven P.H. \& Axelrod D.I. 1974. Angiosperm biogeography and past continental movement. Annals Missouri Botanical Garden, 61:539-673. 
Reginato M. \& Goldenberg R. 2012. Taxonomic notes on Leandra (Melastomataceae, Miconieae). Hoehnea, 39(2):201-206.

Renner S.S. 1993. Phylogeny and classification of the Melastomataceae and Memecylaceae. Nordic Journal of Botany, 13:519-540.

Riccomini C. \& Coimbra A.M. 1992. Geologia da Bacia Sedimentar de São Paulo. In: Negro Jr. A., Ferreira A.A., Alonso U.R., Luz P.A. (eds.). Solos da Cidade de São Paulo, São Paulo, ABMS \& ABEF, p. 37-94.

Riccomini C., Neves F.A.P.S., Turcq B. 1992. Astroblema de Colônia (São Paulo, Brasil): estágio atual de conhecimento. In: SBG, $37^{\circ}$ Congresso Brasileiro de Geologia, Roteiro de Excursão, v. 3, $15 \mathrm{p}$.

Riccomini C., Sant'Anna L.G., Ferrari A.L. 2004. Evolução Geológica do Rift Continental do Sudeste do Brasil. In: Mantesso-Neto V., Bartorelli A., Carneiro C.D.R., \& Brito-Neves B.B. (eds.). Geologia do Continente Sul-Americano: evolução da obra de Fernando Flávio Marques de Almeida. São Paulo, Beca, p. 383-405.

Rodrigues-Lima A.A. \& Affonso P. 2010. Levantamento de Leandra Raddi no Núcleo Curucutu, Parque Estadual da Serra do Mar, São Paulo. Revista do Instituto Florestal, 22(1):15-32.

Santos D.B. 2005. Palinologia de amostras da seção tipo da Formação Itaquaquecetuba, Bacia de São Paulo, na Mineradora Itaquaréia 1: Implicações Palinocronoestratigráficas e Paleoambientais. Course Completion Assignment, Graduação em Ciências Biológicas, Universidade Guarulhos, 148 p.

Santos D.B. 2008. Reconstituição da paisagem paleógena, com base na paleopalinologia, da Formação Itaquaquecetuba (Mineradora Itaquaréia 1), bacia de São Paulo, Brasil. M.Sc. Dissertation, Universidade Guarulhos, Guarulhos, 204 p.

Santos D.B. 2009. A paleopalinologia na reconstituição da paisagem paleógena na Formação Itaquaquecetuba (Mineradora Itaquareia 1), Bacia de São Paulo, Brasil. MS Dissertation, Universidade Guarulhos, Guarulhos, 302 p.

Santos D., Garcia M.J., Fernandes R.S., Saad A.R., Bistrichi C.A. 2006a. A paleopalinologia na reconstituição da paisagem terciária da Formação Itaquaquecetuba (Mineradora Itaquareia 1), Município de Itaquaquecetuba, Estado de São Paulo, Brasil. In: SBG, 13 Simpósio Argentino de Paleobotânica y Palinologia, Anais, p. 72.

Santos D., Garcia M.J., Fernandes R.S., Saad A.R., Bistrichi C.A. 2006b. A composição paleopalinoflorística dos depósitos terciários da Formação Itaquaquecetuba (Mineradora Itaquareia 1), Município de Itaquaquecetuba, Estado de São Paulo, Brasil. In: 70 Simpósio do Cretáceo do Brasil e I Simpósio do Terciário do Brasil, Boletim, p. 20.
Suguio K. 1971. Estudo dos troncos de árvores lignificadas dos aluviões antigos do rio Pinheiros (SP). Significados geocronológico e possivelmente paleoclimático. In: SBG, $25^{\circ}$ Congresso Brasileiro de Geologia, Anais, p. 63-69.

Suguio K \& Mussa D. 1978. Madeiras fósseis dos aluviões antigos do Rio Tietê, São Paulo. Estudos anatômicos e paleoecológicos. Boletim IG USP, 9:25-45.

Suguio K. \& Takahashi L.I. 1970. Estudo dos aluviões antigos dos rios Pinheiros e Tietê, São Paulo, SP, Anais da Academia Brasileira de Ciências, 42(3):555-570.

Takiya H. 1997. Estudo da sedimentação Neogênico-Quaternária no município de São Paulo: caracterização dos depósitos e suas implicações na geologia urbana. PhD Thesis, Instituto de Geociências, Universidade de São Paulo, São Paulo, 152 p.

Takhtajan A.L. 1980. Outline of the classification of flowering plants (Magnoliophyta). The Botanical Review, 46:225-359.

Tolentino M. 1965. Algumas considerações sobre um carvão da bacia de São Paulo. Geologia, 135(13):29-33.

Tufano P. 2009. Tafoflora neógena da Formação Pindamonhangaba, Bacia de Taubaté, Estado de São Paulo, Brasil. MS Dissertation, Instituto de Geociências, Universidade Guarulhos, Guarulhos, $200 \mathrm{p}$.

Van der Hammen T. \& García de Mutis C. 1966. The Paleocene pollen flora of Colombia. Leidse Geologische Mededelingen, 35:105-114.

Vaz A.M.S.F. \& Tozzi A.M.G.A. 2005. Sinopse de Bauhinia sect. Pauletia (Cav.) DC. (Leguminosae: Caesalpinioideae: Cercideae) no Brasil. Revista Brasileira de Botânica, 28:477-491.

Wunderlin R.P. 2009. Revision of Bauhinia subgenus Bauhinia section Pauletia Series Ariaria (Cercideae: Caesalpinioideae: Fabaceae). Journal of the Botanical Research, 3(2):629-637.

Wunderlin R.P., Larsen K., Larsen, S.S. 1987. Reorganization of the Cercidae (Fabaceae: Caesalpinoideae). Det Kongelige Danske Videnskabernes Selskab Biologiske Skrifter, 28:1-40.

Yamamoto I.T. 1995. Palinologia das bacias tafrogênicas do sudeste (bacias de Taubaté, São Paulo e Resende): análise bioestratigráfica integrada e interpretação ambiental. Ms Dissertation, Instituto de Geociências e Ciências Exatas, Universidade Estadual Paulista "Júlio de Mesquita Filho", Rio Claro, 217 p.

Zanão R., Castro J.C., Saad A.R. 2006. Caracterização geométrica de um sistema fluvial, Formação Itaquaquecetuba, terciário da bacia de São Paulo. Revista Geociências, 25(3):307-315.

Arquivo digital disponível on-line no site www.sbgeo.org.br 